Check for updates

The BMJ

Cite this as: $B M J 2021 ; 373: n 1136$ http://dx.doi.org/10.1136/bmi.n1136 Published: 04 May 2021

\title{
Covid-19: Students overlooked for vaccine in favour of family members at Dublin hospital
}

\section{Clare Dyer}

A decision at the Coombe Women and Infants University Hospital in Dublin to give leftover covid-19 vaccine to family members of staff has sparked newspaper headlines, calls for the hospital's master to resign, and allegations that its board is trying to silence a critical consultant.

Senior counsel Brian Kennedy, commissioned to establish the facts on the incident by the hospital board, was told that, on the evening of 8 January, the queue for vaccinations of frontline workers "thinned out quickly shortly after $8.30 \mathrm{pm}$, which was unanticipated." ${ }^{1}$ Vials of Pfizer-BioNTech vaccine drawn up had to be used by 2.30 am or discarded, Kennedy was told. He reported that, after a "short and informal conversation" between 11 individuals, a consensus was reached that any leftover doses should be made available to family members of those present.

Michael O'Connell, master of the hospital and a consultant obstetrician, accepted in his interview with Kennedy that if he had been against giving the vaccines to family members, it would not have happened. At the time, clinical guidance was that doses that could not be used in time should be discarded, although guidance issued soon afterwards provides for a standby list of healthcare workers to be drawn up and for no dose to be wasted.

Most of the family members who were vaccinated went to the hospital, but one consultant obstetrician took leftover doses home to administer to two family members. O'Connell told Kennedy that if that doctor was "comfortable to take the vaccine home," he was "not standing in their way." In all, 16 vaccinations were administered across eight families. Seven recipients were under the age of 70, and O'Connell gave jabs to two of his children.

Deirdre Murphy, head of obstetrics and gynaecology at Trinity College Dublin and a consultant at the Coombe, told Kennedy that she had provided a pro-forma to the senior executive team at the hospital for 39 medical students who were on standby to be vaccinated should doses be left over. None of the medical students were vaccinated. Kennedy reported that O'Connell and other staff who were present on the Friday evening were not aware that any medical students were standing by.

In a letter copied to the consultants at the hospital, Murphy wrote, “A great deal of effort went into preparing the documentation for medical students to be vaccinated, and Dr O'Connell chose to vaccinate his children instead." She questioned the accuracy of Kennedy's report and O'Connell's explanations for what happened and called on O'Connell to resign. His predecessor as master, Chris Fitzpatrick, told the
Irish Times that O’Connell "must be held ultimately accountable. What happened should never have happened."

Murphy also emailed the minister for health, Stephen Donnelly, and Paul Reid, CEO of the Health Service Executive (HSE), outlining her concerns. On 14 April the hospital board's chairperson, Mary Donovan, wrote to her expressing the board's "disappointment" with Murphy's "entirely inappropriate" manner of bringing her concerns "to the attention of a significant number of individuals.” The board thought that she had "sought to undermine its authority and the good governance of the Coombe," Donovan wrote. "As an employee of the Coombe, there are avenues available for you to raise your concerns internally and these must be followed."

Murphy replied on 20 April taking issue with some of Donovan's statements. She wrote, “The CEO of the HSE and the minister for health are entitled to be made aware of the deficiencies in the published report." She added, "No institution should be above questioning, and no individual should be threatened for posing valid questions."

Murphy also spoke at a consultants' meeting on 20 April attended by members of the board. On 26 April her husband Tom Fahey, professor of general practice at the Royal College of Surgeons in Ireland University of Medicine and Health Sciences, wrote to the minister for health accusing the board of attempting to "threaten, intimidate and isolate" her.

The hospital board said in a statement,

"Notwithstanding mitigating factors, the board accepts that mistakes were made, not least in the decision to vaccinate family members and, in one case, in the administration of two vaccines offsite. Lessons must and will be learnt to ensure that similar issues cannot recur."

Minister for health Stephen Donnelly told the national broadcaster RTE that what had happened was "absolutely wrong" and he did not agree with the board's view that there should be no further sanctions. He said that he would be engaging with the board and added, "I'm not satisfied with the answer back from the board at this time."

The BMJ asked O'Connell for a comment but at the time of going to press no reply had been received.

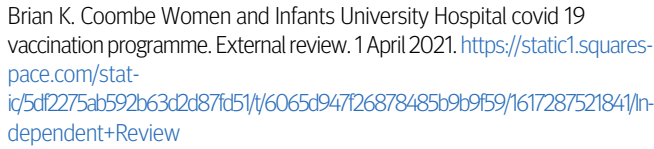

This article is made freely available for use in accordance with BMJ's website terms and conditions for the duration of the covid-19 pandemic or until otherwise 
determined by BMJ. You may use, download and print the article for any lawful, non-commercial purpose (including text and data mining) provided that all copyright notices and trade marks are retained. 